Conference Paper

\title{
Optimization of capital structure with cost of capital as a measurement
}

\author{
Sri Trisnaningsih ${ }^{1 *}$, Failasuf Herman Hendra ${ }^{2}$ \\ ${ }^{1}$ Accounting, Faculty of Economic and Business Universitas Pembangunan Nasional "Veteran" Jawa Timur, \\ Indonesia \\ ${ }^{2}$ Department of Architecture, Institut Teknologi Adhi Tama Surabaya, Indonesia
}

*Corresponding author:

E-mail: trisna.ak@upnjatim.ac.id

\begin{abstract}
The purpose of the present study was to prove that the weighted average cost of capital can be used as a measurement of capital structure optimization. The sample was nine food and beverage companies listed in the Indonesia Stock Exchange from 2015 to 2019 taken secondary data were used with a quantitative approach. Hypotheses were tested by using multiple linear regression analysis. Analysis showed that simultaneously had significant effects on the cost of capital. Partial analysis showed that the debt to asset ratio affected the cost of capital. The long-term debt to equity ratio and net profit margin partially did not affect. Comparison of means showed that return on investment was lower than the means of the WACC. Thus, it can be concluded that the weighted average cost of capital can be used as a benchmark of capital structure optimization with the weighted average cost of capital as the minimum rate of return on investment.
\end{abstract}

Keywords: Capital structure, WACC, return on investment

\section{Introduction}

A capital structure is combined funding of investment originated from equity capital or loan capital. Both components of the capital structure can give rise to the cost of capital. The weighted average cost of capital can be calculated based on the cost of capital, which will then be used as an indication of the minimum rate of return on investment that has been made by the company. To obtain an indication of the capital structure optimization, the WACC should be compared to the return on investment (earning power). Riyanto (2001) suggests that the concept of cost of capital is the optimum capital structure, a capital structure that can minimize the average cost of capital. The amount of the cost of capital depends on the proportion of each source of capital as well as the cost of each component of the source of capital.

The debt to total assets ratio is a ratio used as a parameter for measuring the ratio of total debt to total assets of the company. The ratio of debt to total assets is obtained from the company's total debt divided by total assets. This ratio can indicate the amount of the debt used for the funding of investment in the form of current assets, fixed assets, and other assets. According to Gitman (2000), this ratio emphasizes the importance for a company by showing the percentage of the company's assets supported by debt financing. The greater the debt to total assets ratio the greater the company's dependence on external parties and the greater the cost of capital borne by the company will be. The increasing ratio of debt to total assets has an impact on the company's profitability since some of it is used to pay the interest on the loan. Conversely, the lower the debt to total asset ratio, the smaller the cost of capital borne by the company will be. Thus, debt to a total assets may affect the rate of cost of capital. 
LDER is the ratio of long-term debt to equity capital. This ratio has also been used to the extent to which the long-term debt is collateralized by equity capital (Riyanto, 2001). The purpose is to measure how much of every dollar of equity capital is collateralize Increasing longterm debt to equity ratio indicates a greater composition of long-term debt than equity capital. This leads to lower equity capital collateral than long-term debt and at the same time will affect the capital structure, which will ultimately have an impact on the cost of capital.

Net profit margin is the ratio that indicates the percentage of net profit earned from each sale (Riyanto, 2001). This ratio shows the level of efficiency of the company or the extent to which the company can reduce operating costs in certain periods. The greater the ratio the better will be. Conversely, the lower the ratio the worse sales will be. (Trisnaningsih, 2016). When the net profit margin increases, the retained earnings will also increase. Thus, the components of the capital structure of share capital (dividends borne by the company) will also change according to the increase in the total equity.

Previous studies have rarely investigated the asset and associated with the cost of capital concerning capital structure optimization. Hence, the researcher was interested to conduct a further study of capital structure optimization by using the cost of capital as a measurement.

Capital structure constitutes one of the complicated financial decisions as it relates to other variables. A decision of capital structure can lead to a high cost of capital; thus, an effective financial decision can lower the cost of capital (Sundjaja, 2003). The most important criteria in selecting the components of funding source are the lowest. About the concept of cost of capital. Gaver \& Kenneth (2003) makes it clear should funding these sources. A company's internal funding sources derive from retained earnings and depreciation. External funding sources can be divided into debt financing and external equity. Mixed-use of equity capital (both common stock and preferred stock) and debts to meet the financing needs of the company is the capital structure of the company. In a similar vein, Barclay and Watts (1995) states the addition of debts and at the same time increase the expected rate of return. As such, is required, optimizes the balance of the risk and the rate of return (Erwita, 2010). The capital structure was chosen to address the issue of how much capital requirements are used by the company is the one that maximizes the value of the company. Weston and Copeland (1996) argue that an optimal capital structure is the one that optimizes the balance of risk and return. An optimal capital structure is often referred to as targeted since the value is maximized and tends to be minimized. Targeted relates to the financial leverage (Erkaningrum, 2008).

Concept of a highly in company spending. This concept is aimed at determining the number of costs that must be borne by the company to obtain funds (Riyanto, 2001). The Cost of Capital from a managerial perspective is the rate of exchange to make a decision. Cost of capital is the costs that are taken into account due to the use of a certain capital, whether it is incurred to obtain such capital or to be taken into account during the use of the capital in question. A company's cost of capital depends on the expected return of all securities issued by the company (Sylvia, 2012).

In conclusion, a capital structure is considered optimum when the ROI is higher than the WACC. Conversely, a capital structure is considered not optimum when the ROI is lower than the WACC. Currently, many IDX-listed manufacturing companies with a sizeable capital structure consisting of equity financing and debts have suffered substantial losses, causing equity deficit. Also, many companies involve considerable investments but provide a very small amount of profits. Based on the theoretical basis and reasonable thinking, several hypotheses were formulated:

$\mathrm{H}_{1}$ : DAR, LDER, and NPM have effects on WACC.

$\mathrm{H}_{2}$ : Lower WACC than average ROI serves as benchmark capital structure optimization. 
The relationship among four or more variables could be determined by using the multiple regression analysis. The conceptual Framework for the study can be seen in Figure 1:

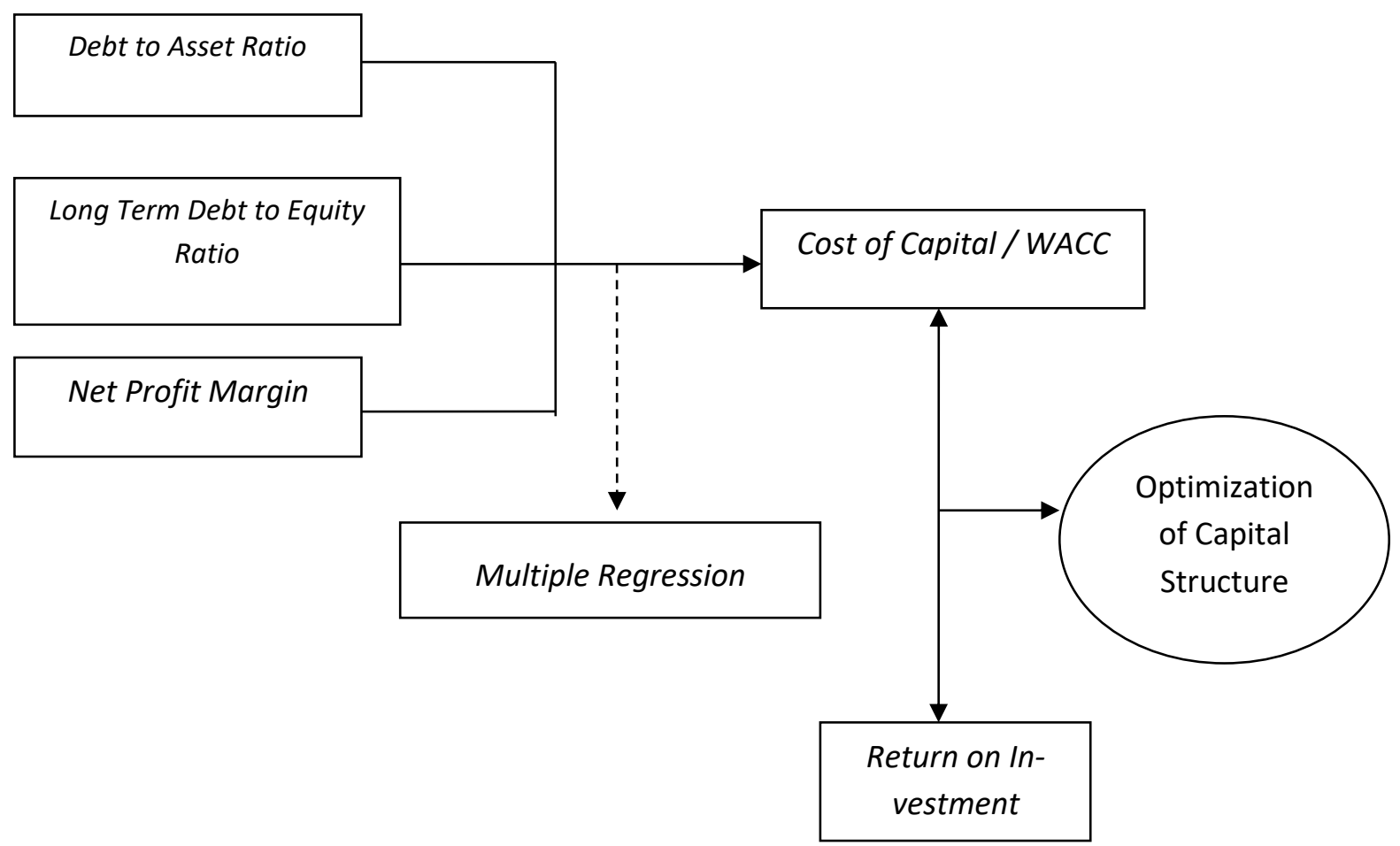

Figure 1. Conceptual framework

\section{Material and Methods}

The study population was food and beverage companies listed on Indonesia Stock Exchange. Samples were taken by using a purposive sampling method. The inclusion criterion was the company that has published its financial statements over 5 years (2015-2019). Nine food and beverage companies were included.

WACC is the actual cost borne by the company, which is the overall cost for all users. WACC is measured by (Weston \& Brigham, 1990):

1. Debt to asset ratio, or the ratio of the book value of the entire debt to total assets.

2. LDER, or the long-term debt to equity capital used by the company.

3. Net profit margin, one of the ratios used to measure profitability. This ratio measures how much net operating profit to be gained from every dollar of sales. The higher the net profit margin, the better a company's operation will be.

\section{Analysis and hypothesis testing}

A multiple linear regression analysis was used in this study. F-test, which is a test of the fit of the regression analysis model, was used to determine whether the independent variables, which were the balance of DAR, LDER, and NPM had simultaneous. The $t$-test was to examine the significance of the effects of asset, LDER, and NPM on the cost of capital partially. This test was individual the variables in IDX-listed food and beverage companies.

\section{Results and Discussion}

Results of the simultaneous analysis showed an $F$-test of 7.907 with a significance of 0.003 . This implied three had effects on the WACC. Thus, WACC could be used as a benchmark of 
capital structure optimization with the WACC as a minimum rate of return on investment. Table 1 below shows the results of the simultaneous analysis.

Table 1. Results of simultaneous analysis

ANOVA $^{b}$

\begin{tabular}{|c|c|c|c|c|c|c|}
\hline & Model & Sum of Squares & $\mathrm{df}$ & Mean Square & $\mathrm{F}$ & Sig. \\
\hline \multirow[t]{3}{*}{1} & Regression & 12.134 & 3 & 4.045 & 7.907 & $.003^{\circ}$ \\
\hline & Residual & 17.407 & 41 & .587 & & \\
\hline & Total & 29.540 & 44 & & & \\
\hline
\end{tabular}

a. Predictors: (Constant), X3_NPM, X2_LDER, X1_DAR

b. Dependent Variable: Y_WACC

Table 2. Results of partial analysis ( $t$-test)

\section{Coefficients ${ }^{\mathbf{a}}$}

\begin{tabular}{|c|c|c|c|c|c|c|c|c|}
\hline \multirow{2}{*}{\multicolumn{2}{|c|}{ Model }} & \multicolumn{2}{|c|}{$\begin{array}{l}\text { Unstandardized Coeffi- } \\
\text { cients }\end{array}$} & \multirow{2}{*}{\begin{tabular}{|c|}
$\begin{array}{c}\text { Standard- } \\
\text { ized Coeffi- } \\
\text { cients }\end{array}$ \\
Beta
\end{tabular}} & \multirow[b]{2}{*}{$\mathrm{T}$} & \multirow[b]{2}{*}{ Sig. } & \multicolumn{2}{|c|}{$\begin{array}{c}\text { Collinearity Statis- } \\
\text { tics }\end{array}$} \\
\hline & & B & Std. Error & & & & $\begin{array}{l}\text { Toler- } \\
\text { ance }\end{array}$ & VIF \\
\hline \multirow[t]{4}{*}{1} & $\begin{array}{l}\text { (Con- } \\
\text { stant) }\end{array}$ & 3.292 & .733 & & 4.495 & .001 & & \\
\hline & X1_DAR & 2.725 & 1.317 & -.403 & 2.072 & .049 & .544 & 1.839 \\
\hline & X2_LDER & .104 & .519 & .033 & .198 & .845 & .734 & 1.363 \\
\hline & X3_NPM & 6.607 & 3.233 & .352 & 2.044 & .061 & .691 & 1.448 \\
\hline
\end{tabular}

a. Dependent Variable: Y_WACC

The partial debt to asset ratio had a significance of $0.049<0.05$, meaning that DAR had a significant effect on WACC. It could be concluded the higher the ratio the higher the risk will be. This ratio raised the cost of capital in the funding activity for the continuity of the company.

Results of partial hypothesis testing for LDER by use $t$-test showed a significance of 0.845 $>0.05$, meaning that LDER did not affect WACC. The LDER in the capital structure of the food and beverage companies sampled in the study for 2015-2019 was 29\%, on average. The equity capital in the capital structure was larger (78\%) $(* 100 / 129)$. This ratio showed that the majority of the sampled companies had low long-term debts $(22 \%)(* 29 / 129)$. The cost of capital in the capital structure for the long-term debt to equity ratio was also low, following the LDER level. This was because in the period of sampling most of the sampled companies had already paid their long-term debts. 
Partial net profit margin had a significance of $0.061>0.05$, indicating that net profit margin did not affect WACC. This was because, on average, the companies sampled in 2015 to 2019 had a low rate of profits ( 0.06 or $6 \%)$. This led to a small growth of retained earnings; thus, the cost of capital itself became small.

Overall, the companies showed a lower return on investment than their WACC. This demonstrated that the capital structure of the 9 companies sampled in this study was not optimal since the profits generated by those companies over 5 years were quite small, leading to a minimum return on investment. The small number of profits was caused by the suboptimal profit-generating performance of the company. Theoretically, an optimal that can minimize the average cost of capital usage and should be kept below the rate of return on investment. To achieve an optimal capital structure, companies should take into account the costs arising from the fulfillment of capital. Also, it should be offset by an increase in the company's performance in meeting the company's objective of achieving an increase in earnings without being disturbed by the obligation to fulfill the WACC. It evident that WACC can be used as a benchmark of capital structure optimization by comparing the return on investment and WACC following the theories described and substantiated in this study.

\section{Conclusion}

1. The variables simultaneously contributed significantly to the cost of capital. The debt to asset ratio contributed partially to the cost of capital. Long-term debt to equity ratio and net profit margin had no effect on the cost of capital.

2. Cost of capital can be used as a measurement of capital structure optimization by comparing the average return on investment with WACC of the IDX-listed food and beverage companies.

\section{References}

Barclay, M. J., \& Watts, R. L. (1995). The determinants of corporate leverage and dividend policies. Journal of Applied Corporate Finance,7 (4), 4-19.

Erkaningrum, I. (2008). The determinants of the capital structure. Journal of Accounting and Business, 1 (2), 164-174

Erwita, D. (2010). The influence of capital structure to profit optimization (case studies on companies who go public in the list Jakarta Islamic Index Period 2001-2005). The Indonesian Journal of Accounting Research, 4(1), 1-8.

Gaver, J., \& Kenneth M. G. (2003). Additional evidence on the association between the investment opportunity set and corporate financing, dividend, and compensation policies. Journal of Accounting and Economics, 16, 125-160

Gitman, J. L. (2000). Principles of managerial finance. Ninth Edition. Addison Wesley Longman, Inc .

Riyanto, B. (2001). Dasar-dasar pembelanjaan perusahaan. Fifth Edition. Yogyakarta: BPFE UGM

Sundjaja. (2003). Financial management. Fourth Edition. Jakarta: Salemba Publishing.

Sylvia, S. (2012). The relationship between the cost of equity capital with the level of social responsibility disclosure and intellectual capital in the Banking Sector In Indonesia. Accounting and Auditing Journal, 9(1), 71 - 74.

Trisnaningsih, S. (2016). Cost of capital as a benchmark of capital structure optimization. The Social Sciences, 11(18), $4473-4477$.

Weston, J. F., \& Brigham, E. F. (1990). Essentials of managerial finance. Ninth Edition. The Dryden Press.

Weston, J. F., \& Copeland, T. E. (1996). Financial theory and corporate policy. Eight Edition. Tokyo: The Dryden Press CBS Publishing. 